\title{
Mobilização política dos imigrantes africanos no Atlântico Sul pela conquista de direitos em São Paulo: o caso da morte da Zulmira em 2012
}

\begin{abstract}
La mobilisation politique des immigrants africains dans l'Atlantique Sud pour la conquête de droits à São Paulo: le cas de la mort de Zulmira en 2012
\end{abstract}

\section{Bas'Ilele Malomalo*}

Resumo: O presente texto, construído a partir da pesquisa documental em combinação com o dispositivo da experiência vivenciada do autor e da memória coletiva, é uma pequena narrativa sobre as mobilizações políticas dos imigrantes africanos organizados coletivamente em São Paulo, no período de 2012 a 2015, para lutar contra o racismo, a violência e a insegurança que afetam suas vidas. Deste ponto de vista, são vistos como sujeitos históricos que se mobilizam pelos direitos da cidadania dos imigrantes.

Palavras-chave: migração; africanos; mobilização.

Résumé: Ce texte, écrit à partir des sources documentaires en combinaison avec les dispositifs de l' expérience vécue et la mémoire de son autor, se présente comme une petite narrative au tour de mobilisations politiques des immigrants africains articulées coletivement dans les provinces de São Paulo, durant la période de 2012 à 20I5, lutant contre le racisme, la violence et l'insécurité qui affectent leur vie. De ce point de vue, ils sont vus comme sujets historiques qui se mobilisent en faveur des droits de la citoyenneté d'immigrants.

Mots-clés: migration; africains; mobilisatiom.

\footnotetext{
Doutor em Sociologia, docente no programa de Mestrado Interdisciplinar em Humanidades, Instituto de Humanidades e Letras/Universidade da Integração Internacional da Lusofonia Afro-Brasileira, São Francisco do Conde, Bahia, Brasil; líder do Grupo de pesquisa África-Brasil: Produção de conhecimento, Sociedade civil, Desenvolvimento e Cidadania Global; integrante e fundador do IDDAB. Contato: basilele@unilab.edu.br.
} 


\section{Zulmira Descanse em Paz}

Nós não somos simplesmente negros no país do futebol, Somos seres humanos em busca de uma formação digna, mas Enquanto vocês nos olharem com essa diferença, o mundo será Vítima desse vosso preconceito, Brasil. (KANHANGA, 2013) ${ }^{\mathrm{I}}$

\section{Introdução}

Este texto pertence aos estudos que investigam os imigrantes africanos no Brasil no contexto dos séculos XX e XXI. É parte do meu ofício e dever de intelectual e ativista compromissado com os problemas que afetam a comunidade africana. Trata-se da contribuição que um imigrante africano, radicado na Diáspora Africana no Brasil, pode dar para este dossiê sobre a História do Atlântico e da Diáspora Negra.

Seus objetivos são modestos: sistematizar informações e construir uma narrativa sobre as lutas políticas protagonizadas pelas associações dos africanos, junto com outras de direitos humanos e antirracistas, no Atlântico Sul-Brasileiro, no período de 2012 até 20I5, no Estado de São Paulo. Essa periodização obedece à data do assassinato da estudante angolana Zulmira de Souza Borges Cardoso, o julgamento popular e o encarceramento de um dos seus assassinos.

Com isso, pretende-se compreender, numa perspectiva interdisciplinar, as formas de organizações coletivas de defesa dos direitos coletivos, dos direitos humanos e de acesso à justiça numa sociedade em que a violência, o racismo, a discriminação e a xenofobia assolam a vida dos negros e, de modo particular, a dos negros africanos.

Para tornar vivo e compreensível o texto, começo com indagações metodológicas em torno da interdisciplinaridade: a apresentação da escolha dos documentos e suas intepretações; e, em seguida, faço colocações teóricas sobre os termos da Diáspora Negra para estabelecer uma diferença dentro dela, considerando os sujeitos que a compõem: os descendentes de africanos trazidos ao Atlântico Sul-Brasileiro entre os séculos XVI e XIX e a Diáspora Africana contemporânea formada pelos imigrantes africanos e seus descendentes, que vêm migrando desde o século XX até o XXI. Na última seção, elaboro a minha narrativa sobre a morte da Zulmira Cardoso em São Paulo e, consequentemente,

\footnotetext{
I Rapper angolano, nascido em 6 de março de 1986. Em 2005, veio ao Brasil fazer o curso de Administração depois de ter ganhado uma bolsa de estudo em Porto Alegre, cidade onde vive atualmente.
} 
aponto a forma de mobilização coletiva que levou os migrantes africanos a exigir a justiça sobre o caso às autoridades.

\section{Migrações metodológicas: a interdisciplinaridade e a narrativa sobre as memórias}

A abordagem interdisciplinar adotada, neste texto, inspira-se dos Estudos Africanos (HOUNTONDJI, 20IO; KI-ZERBO, 20IO), que, geralmente, acionam as competências das Ciências Humanas e Sociais para se estudar os fenômenos sociais. Falando da especificidade interdisciplinar da História da África, Odile Goerg (I99I, p. I45) faz a observação que é o campo, talvez ainda mais do que os outros, "[...] marcado pela interferência de outras disciplinas (Sociologia, Antropologia, Politologia...) sem que os limites estejam sempre marcados nitidamente [...]" (nossa tradução).

De fato, existem estudos disciplinares sobre a África e suas diásporas. Porém, desde as renovações das Ciências Sociais e Humanas que ocorreram em todo mundo, no contexto dos anos sessenta, existe pelo menos um consenso de que não há como produzir conhecimentos hoje negligenciando-se a interdisciplinaridade (CASANOVA, 2006; MORIN, 2OII). Os cientistas sociais que têm a África como objeto de investigação costumam trabalhar nessa perspectiva (HOUTONDJI, 20IO).

Este texto emprega a pesquisa documental e a pesquisa bibliográfica na coleta de materiais (GIL, 1996). A primeira modalidade reuniu suas fontes selecionando vídeos, atas de reuniões, textos divulgados em jornais eletrônicos e em redes sociais como blogues, Facebook, referentes aos sujeitos do campo desta investigação, e algumas imagens que registraram os momentos da luta e organização coletiva das comunidades africanas que foram promovidas pelos próprios imigrantes africanos e/ou por terceiros, as organizações sociais de direitos humanos e as autoridades do poder público, com intuito de atender às suas demandas.

Os documentos selecionados são o que Jacques Le Goff (2012, p. 509) denomina de "materiais de memória coletiva"; e Benedito Medrado (1999) classifica de "textos em cena", considerando aqueles que são produzidos na mídia. $\mathrm{O}$ autor deste texto é parte da memória coletiva da Diáspora Africana contemporânea no Brasil (MALOMALO; FONSECA; BADI, 2015), e serve-se, na sua escrita, da sua experiência de imigrante-testemunha dos acontecimentos narrados aqui, levando em conta a sua participação na qualidade de ativista social do movimento negro brasileiro, do movimento dos imigrantes africanos; de ser articulador do Instituto do Desenvolvimento da Diáspora Africana no Brasil (IDDAB), como residente, primeiramente, em São Paulo e, depois, no Ceará (nas cidades de 
Redenção, Fortaleza e Pacatuba) e na qualidade de docente da Universidade da Integração Internacional da Lusofonia Afro-Brasileira (UNILAB).

A memória coletiva dos imigrantes africanos, registrada nos documentos, é acionada como parte do dispositivo analítico-interpretativo deste texto. Valorizam-se, aqui, as epistemologias africanas na elaboração da narrativa sociológico-histórica que lhes dá sentido. Parafraseando Manthian Diawara ${ }^{2}$, citado por Maria Antonieta Antonacci (2015, p. 349), em Memórias encoradas em corpos negros, afirmo que é comum os cientistas africanos das Humanidades, ao fazer a ciência usam o "estilo griótico", recorrendo, geralmente, às formas de narrativas orais das tradições de seus ancestrais, construindo, assim, um discurso científico com um estilo próprio que valoriza, por exemplo, os gestos estilizados, e principalmente, utilizando as palavras/discursos como armas que podem matar ou libertar.

A experiência, a memória individual do autor deste texto, para assegurar a sua objetividade, retomando a expressão de Bourdieu (2001, 2002), foi submetida à crítica radical, isto é, confrontada com outras memórias provenientes de fontes documentais (textos de jornais, áudios e/ou audiovisuais) e com fontes bibliográficas que dão suporte à construção de todo seu texto. A bibliografia selecionada é especializada na temática da Diáspora Africana contemporânea e não deve ser confundida com aquela que trata das relações raciais no Brasil. Embora exista a possibilidade de esta última ser usada, como se fez aqui, para elucidar o racismo que afeta os imigrantes africanos, não se deve confundilas. Cada realidade tem a sua especificidade e é isso que nos interessa.

Os documentos, que retratam a memória coletiva dos imigrantes africanos, são considerados, para usar a expressão de Madrado (1994), como "texto em cena" no sentido que nos possibilitam compreender suas lutas e suas mobilizações pelos direitos dentro da sociedade brasileira. Dito em outras palavras, compreendo a utilidade da proposta analítica tríplice de Medrado (1999) sobre os textos em cena da mídia enquanto práticas discursivas. Este autor se inspira em John Thompson, e sugere que se analisem os textos midiáticos, considerando-se três passos: I) a produção e transmissão ou difusão das formas simbólicas; 2) a construção da mensagem dos meios de comunicação; e 3) a recepção e a apropriação dessa mensagem.

Concordo com tudo isso, todavia, por uma questão de afinidade teóricometodológica ficarei com a proposta analítica de Bourdieu, em que toda prática discursiva antes de mais nada é uma prática social. Fora certas diferenças conceituais, o que guardo

\footnotetext{
${ }^{2}$ Nascido em Bamako (Mali) em I953, é cineasta, professor de Literatura Comparada e de Cinema, diretor dos Estudos Africanos e do Instituto Afro-Americano da Universidade de Nova York (Estados Unidos).
} 
do Medrado e outros pesquisadores ${ }^{3}$ que fazem uso das teorias de práticas discursivas ou de análise de/do discurso é a busca da apreensão dos sentidos produzidos pelos agentes sociais que estariam presentes nos seus produtos como textos midiáticos que nos interessam aqui.

O texto faz uso do método genético-estrutural e da oralidade à l'africaine para a análise e interpretação do material coletado. A análise genética, como relembra Bourdieu (1982, 200I), exige que o pesquisador faça a história social do campo do seu estudo, que o obriga a saber tratar o tempo, a periodização dos acontecimentos de sua análise, e trabalhar criticamente com o espaço, enquanto campo de produção dos materiais em análise. Dessa forma é que os documentos selecionados são tratados como registros históricos de africanos fazendo história de mobilização, luta e resistência para assegurar seus direitos de cidadania em São Paulo no período de 2012-2015. Realizou-se, igualmente, a crítica documental radical, verificando-se a (re)produção, quando necessário, de uma matéria jornalística em mais de um veículo de comunicação (BOURDIEU, I982, 200I; LE GOFF, 2012).

A análise estrutural de Bourdieu (200I), segundo elemento do seu método, é apropriada aqui como dispositivo sociológico de busca de compreensão, a partir dos documentos, das relações de poder, de dominação, negociações e de resistência dentro do campo que constitui as vidas dos imigrantes africanos na Diáspora Brasileira. Esse momento de análise é aquele em que o pesquisador se preocupa em identificar as relações existentes entre os agentes, indivíduos e instituições, que produzem o campo investigado e, ao mesmo tempo, como estes agentes são reproduzidos por ele.

O que designo por método de oralidade é uma forma africana de narrar cientificamente os acontecimentos históricos que são objeto desta investigação. É o momento de interpretar os dados coletados à luz das teorias (GOMES, 20I2). Devo confessar que Amadou Ampâté Bâ é a minha inspiração predileta, nessa circunstância, no uso da "memória africana" a partir da qual interpreto a história dos imigrantes africanos.

A oralidade é vista por nós como a capacidade de acionar a memória através das palavras. E a narrativa é considerada aqui como a capacidade de descrever uma cena com palavras ou com a escrita.

Em Amkoullele, o menino Fula, falando da memória africana, o mestre Amadou Hampâté Bâ leciona o que segue:

\footnotetext{
${ }^{3}$ Por exemplo: SPINK, Jane Mary (I999); ORLANDI, Eni (20I2); FAIRCLOUHG, Norman (20oI); o Método de Interpretação de Sentidos de Romeu Gomes (20I2) se aproxima, em muito, da proposta bourdieusiana.
} 
Muitos amigos que leram o manuscrito mostraram-se surpresos. Como é que a memória de um homem de mais de oitenta anos é capaz de reconstruir tantas coisas e, principalmente, com tal minúcia de detalhes? $\mathrm{E}$ a memória das pessoas de minha geração, sobretudo a dos povos de tradição oral, que não poderiam apoiar-se na escrita, é de uma fidelidade e de uma precisão prodigiosa. Desde a infância, éramos treinados a observar, olhar e escutar com tanta atenção, que todo acontecimento se inscrevia em nossa memória como uma cera virgem. Tudo lá estava nos menores detalhes: o cenário, as palavras, os personagens e até suas roupas. Quando descrevo o traje do primeiro comandante de circunscrição francês, eu vejo em uma espécie de tela de cinema interior e basta contar o que vejo. Para descrever uma cena, só preciso revivê-la. E se uma história me foi contada por alguém, minha memória não registrou somente seu conteúdo, mas toda cena - a atitude do narrador, sua roupa, seus gestos, sua mímica e os ruídos do ambiente, como os sons da guitarra que o griot Diêli Maadi tocava enquanto WANGRIN me contava sua vida, e que ainda escuto agora... (2003, p. I3).

A questão que Bâ levanta é que o narrador africano, ao contar os acontecimentos históricos pela força da palavra, faz com que a história, toda história dos homens se torne história viva. E é a história de luta pelos direitos dos imigrantes africanos que se pretende transformar em narrativa científica nas páginas que seguem.

\section{Diáspora Africana e imigrantes africanos no Brasil do século XXI}

Prefiro usar o termo diáspora negra, seguindo a linha da historiadora Linda Heyhood (2008), para me referir aos africanos que migraram forçadamente para o Atlântico durante os séculos XVI e XIX e aos seus descendentes, que nasceram no cativo, e no período do pós-abolição. Emprego esse termo porque me permite incluir, dentro da Diáspora Negra, os africanos remanescentes que imigraram durante o século $\mathrm{XX}$ e imigram, ainda, no século XXI, forçada ou voluntariamente, para o Atlântico Sul-Brasileiro (VARGEM; MALOMALO, 2015).

Dentro da Diáspora Negra, estabeleço uma diferença entre aquela, formada historicamente pelos descendentes de africanos e a outra, formada pelos imigrantes africanos, entre os séculos XX e XXI, que residem nos territórios fora do continente africano. Os imigrantes africanos, por exemplo, residentes no Brasil do século XXI, 
compõem o que se chama de Diáspora Africana contemporânea (MALOMALO; FONSECA; BADI, 20I5). Trata-se de uma diáspora composta pelos indivíduos portadores de diversas nacionalidades africanas que vivem ou estão de passagem no Brasil na qualidade de (i)migrantes, estudantes e trabalhadores. São, geralmente, tratados pelos outros ou pelo poder público ${ }^{4}$ como estrangeiros, indivíduos ou coletividades que vieram de fora, e, muitas vezes, encarados como sujeitos que vivem na "terra do outro", pois, como nos lembra Neusa Gusmão (20II), referindo-se à presença dos estudantes africanos no Brasil, ela é marcada pela invisibilidade.

O conceito de diáspora torna-se plausível em Ciências Sociais, porque nos permite conceber o fenômeno migratório não somente como um dado de fluxo, que pode ser compreendido apenas quantitativamente, mas nos possibilita apreender, além dos números, a existência de outras realidades, e as mais importantes, que uma investigação não deve perder de vista, são as dos imigrantes, vistos como sujeitos históricos movidos pelos seus desejos e pelas suas vontades. Pessoas, apesar das contingências históricas, que elaboram, seus projetos de vida. Lutam pela conquista de seus direitos quando são violados. Mobilizam-se coletivamente para serem reconhecidos como cidadãos.

A diáspora nos remete às individualidades, às subjetividades individuais e às coletividades em movimento, com o desejo de permanência ou não em algum território, da nova pátria, ou seja, a nação de acolhida. Diáspora tem a ver com o processo de construção de identidades de sujeitos migrantes, seja dentro de uma comunidade, da nação de pertencimento, de acolhida ou de trânsito. O que Gilroy (200I) e Hall (2006) falam a respeito das identidades diaspóricas dos descendentes dos africanos escravizados nas Américas aplica-se igualmente na análise das identidades dos imigrantes africanos.

Essas identidades devem ser sempre tomadas no plural, levando-se em conta as experiências particulares e coletivas e devem ser vistas como um permanente processo de construção. São projetos de vida inacabados e que tendem a tomar formas híbridas, de pertencer a dois ou múltiplos mundos, mesmo quando seus portadores negam esse processo de sua constituição.

Portanto, o que interessa a este texto são as identidades coletivas que se manifestam em projeto de lutas políticas na "terra do outro" (GUSMÃO, 20II). Por isso são, também, identidades-projetos de resistência (MALOMALO, 20I4) de sujeitos coletivos que lutam pelo seu reconhecimento e a sua inclusão nas políticas públicas de redistribuição e

\footnotetext{
${ }^{4}$ Cf. lei n ${ }^{\circ}$ 6.815, de I9 de agosto de 1980. Disponível em: http://www.planalto.gov.br/ccivil_03/leis/L68I5.htm. Acessado em I4 abril de 2016.
} 
cidadania. Os imigrantes africanos fazem parte de milhões de migrantes que vivenciam as experiências de migração.

O migrante pode ser visto como aquele que foge e busca, é tangido e extravia-se, ambiciona e frustra-se, resigna-se e realiza-se. São muitos os que se perdem na viagem, ficam pelo caminho, regressam e retornam. Parecem tangidos por uma força desconhecida, simultaneamente histórica e telúrica. (IANNI, 2004a, p. 93).

Para compreender os problemas que pesam sobre os imigrantes africanos no Brasil, no século XXI, é preciso levar em consideração a violência racial e a de classe, as que sempre estiveram presentes na formação da nação brasileira, e como as relações capitalistas da atualidade reativam esse passado para estabelecer a dominação de brancos sobre negros (MUNANGA, I999; PAIXÃO, 2006; D’ ADESKY, 200I). São essas experiências negativas do racismo à brasileira que afetam a vida dos negros brasileiros e dos negros africanos (KALY, 200I; SOUSA, 20I4; LANGA, 20I5) e, ao mesmo tempo, tornam singulares suas experiências de (i)migração.

O racismo à brasileira é uma ideologia de hierarquização racial construída historicamente. Fundamenta-se na reprodução da ideia de que o branco é superior ao não branco, o índio e o negro, e que o lugar destes últimos seria a escala baixa da pirâmide. $\mathrm{O}$ fenótipo, nesse sistema hierarquizante, funciona como o passaporte de proveito de privilégios. Nesse sentido é que os indivíduos ou grupos sociais classificados como negros são preteridos. A brancura, como observa Maria Aparecida Bento (2002), no contexto brasileiro, proporciona privilégios aos seus sujeitos brancos, e ter a cor da pele negra é motivo para se ver privado de seus direitos.

O que dificulta o combate ao racismo, observa a maioria dos estudiosos, é a ideologia da democracia racial tematizada inicialmente por Gilberto Freyre. Florestan Fernandes, no contexto da realização de estudos das relações raciais para a UNESCO, nos anos cinquenta, chegou à conclusão de que a democracia racial era um mito inventado pela elite branca brasileira para dominar os negros (GUIMARÃES, I999; IANNI, 2004b).

Numa entrevista dada à revista Fórum, em I2 de fevereiro em 2012, em pleno caloroso debate sobre cotas nas universidades públicas, Kabengele Munanga ${ }^{5}$ chegou a qualificar o racismo à brasileira de "crime perfeito", pois, para ele, o brasileiro racista

\footnotetext{
5 "O nosso racismo é um crime perfeito", entrevista de Kabengele Munanga concedida à Camila Souza Ramos e Glauco Farias. Disponível em: http://www.revistaforum.com.br/2012/o2/og/nosso-racismo-e-um-crimeperfeito/. Acessado em I2 fev. 2016.
} 
costuma rejeitar a sua culpa e a coloca na própria vítima; ou seja, no Brasil, a vítima é responsável pelo racismo que sofre e o racista é inocentado.

Bento (200I), no texto já citado, identificou outros elementos que fazem parte da manutenção da branquitude racista brasileira: o silêncio do branco como se não fosse parte do problema; o narcisismo dos brancos na qualidade de um grupo étnico-racial; a projeção dos seus problemas, para os grupos que eles consideram como inferiores, se traduz em estereótipos sexuais, do tipo os negros africanos ou seus descendentes são "sensuais", em preconceito, de que o negro brasileiro não assume a sua identidade, como se o branco brasileiro assumisse a sua com tranquilidade quando se coloca na frente de um branco nórdico, ou, ainda, a falsa ideia de que o sangue negro é que atrapalha o progresso, como se fossem os negros que tivessem estado no comando das instituições do país desde a sua invasão em I500; e a discriminação racial que traz bônus para os brancos e ônus para os negros.

De qualquer modo, há um entendimento de que o racismo é uma violência simbólica e física com consequências incalculáveis (SILVA; SILVÉRIO, 2003; IANNI, 2004a). O racismo tem uma dimensão estrutural e se manifesta nas relações interpessoais e institucionais. Por isso, fala-se do racismo do cotidiano e do racismo institucional, que criam as desigualdades sociais e raciais (JACCOUD, 2002, 2009; PNUD, 2005).

Os imigrantes africanos, negros, que nos interessam nesta pesquisa, são sujeitos a esse racismo e, muitas vezes, sua situação se complica quando não dominam ainda os códigos da cultura brasileira; mesmo quando os dominam, o fato de ser estrangeiros os coloca numa situação de vulnerabilidade (KALY, 200I; SOUSA, 20I4; LANGA, 2015).

Quantos imigrantes africanos vivem no Brasil, em São Paulo e Ceará? As informações publicadas pelo portal Terra (IMIGRAÇÃO AFRICANA..., 20I4) indicam que os dados da Polícia Federal (PF), aos quais a Agência Efe teve acesso, apontam que, entre 2000 e 2012, o número de residentes e refugiados africanos no Brasil cresceu mais de 30 vezes, mas esses números podem ser ainda maiores se forem levados em conta os "imigrantes ilegais", aqueles que não têm registros oficiais.

O relatório da Polícia Federal, conforme aquela fonte, informa que, em 2000, viviam no Brasil I0.054 ${ }^{6}$ africanos regularizados de 38 nacionalidades, mas o número saltou em I2 anos para 3I.866 cidadãos legalizados provenientes de 48 das 54 nações do continente.

\footnotetext{
${ }^{6}$ A Terra informou que havia I.054 imigrantes africanos. Me parece que houve um erro de digitalização ou de informação mesmo. De acordo com dados divulgados por Desidério (2006) referentes ao Censo Demográfico do Instituto Brasileiro de Geografia e Estatística (IBGE, 200o; Arquivo de Microdados da Amostra), nos anos de entrada - entre 1996 e 2000 -, havia no Brasil I5.568 africanos. Entretanto, não é especificada em qual categoria eles se encontram, se são imigrantes, refugiados ou estudantes.
} 
A maioria das rotas de imigração é a via aérea. Outras são pelo mar e, em alguns casos, há quem vai primeiro aos países da fronteira norte para depois fazer a travessia para o território brasileiro por terra. "Conheço alguns casos raros de pessoas que fugiram do Congo escondidas em navios e sem saber seu destino, que muitas vezes era o porto de Santos", no litoral paulista, afirmou à Agência Efe o padre Paolo Parise, diretor da Casa do Imigrante de São Paulo, principal centro de amparo aos africanos. O abrigo da Pastoral recebe, segundo o padre, imigrantes desde 1978 , em 90\% dos casos estrangeiros e com status de refugiados. De acordo com Parise, antes havia predominância de latino-americanos e, agora, de africanos e haitianos (IMIGRAÇÃO AFRICANA..., 20I4).

A Agência Efe informa, ainda, que a maioria dos africanos, segundo a Polícia Federal, é oriunda dos Países de Língua Oficial Portuguesa (PALOP), como Angola e Cabo Verde, que contam com II.027 e 4.257 cidadãos respectivamente até 2012 (ano dos dados consolidados mais recentes); em seguida vem a Nigéria, com 3.072 imigrantes que regularizaram sua situação. Segundo o coordenador de Políticas para Imigrantes da Secretaria de Direitos Humanos da Prefeitura de São Paulo, Paulo Illes, o aumento da corrente imigratória africana é mais visível após 20I0, quando o fluxo passou a ser contínuo (IMIGRAÇÃO AFRICANA..., 20I4).

\begin{tabular}{|c|c|}
\hline \multicolumn{2}{|c|}{ Quadro I: Número de residentes e refugiados africanos no Brasil, 2000-20I2 } \\
\hline 2000 & 2012 \\
\hline I0.054 & 31.806 \\
\hline \multicolumn{2}{|c|}{ Fonte: Elaboração do autor a partir dos dados do portal Terra (IMIGRAÇÃO AFRICANA..., 2OI4) } \\
\hline
\end{tabular}

Quadro 2: Nacionalidades africanas com maior número de imigrantes no Brasil

\begin{tabular}{|c|c|c|}
\hline Cabo Verde & Angola & Nigéria \\
\hline II.027 & 4.257 & 3.072 \\
\hline
\end{tabular}

Fonte: Elaboração do autor a partir dos dados do portal Terra (IMIGRAÇÃO AFRICANA..., 2OI4).

Para Desidério (2006), a maioria da população imigrante africana está concentrada na região Sudeste (I2.272), seguida do Sul (I.498), depois vem Nordeste (983), Centro-Oeste (559) e a Norte fica com o menor número (256). A informação mais recente, que apuramos, aponta a existência de 600 mil migrantes em São Paulo, entre os quais, 4.000 são africanos (DENIZ, 20I6). 
Essa é a Diáspora Africana que nos interessa neste trabalho. Nas próximas seções, concentrarei a minha narrativa nos acontecimentos em que ela foi a protagonista na luta pelos seus direitos. Construirei a minha narrativa, como leciona Paul Veyne (1957), a partir de tramas e vestígios que os documentos selecionados me oferecem. Ou seja, apresentarei os problemas que os imigrantes africanos enfrentaram e como tentaram resolvê-los, fazendo uso de estratégias.

\section{A morte da Zulmira Cardoso: onde tudo começou}

$\mathrm{Na}$ manhã do dia 23 de maio de 20I2, antes de ir ao meu trabalho, lecionar na faculdade, fui tomar o meu café e ver as notícias no notebook à minha frente. Logo que abri o meu e-mail, recebi a notícia da morte da estudante angolana Zulmira Cardoso e o ferimento de seus companheiros. Fui conferir nos jornais eletrônicos e me deparei com esta notícia no Estadão.

\section{Discussão de bar termina com universitária angolana morta em SP}

Uma discussão de bar na rua Cavalheiro, no Brás, região central de São Paulo, terminou com uma universitária angolana morta e três outros angolanos feridos na noite de terça-feira (22). Até as 3h3o, ninguém havia sido preso.

Segundo testemunhas, os angolanos estavam bebendo em um bar quando dois outros clientes, brasileiros, teriam xingado o grupo, com termos como "macacos". Houve uma discussão e os brasileiros foram embora.

Cerca de 20 minutos depois, um dos brasileiros voltou, em um Golf prata, desceu do veículo e atirou contra o grupo de angolanos. Zulmira de Souza Borges Cardoso, 26, estudante de engenharia na Uninove, foi atingida e morreu no local. Celina Bento Mendonça, 34, grávida de cerca de oito meses, acabou ferida por pelo menos dois tiros, um deles na barriga. Gaspar Armando Mateus, 27, foi baleado na perna. Renovaldo Manoel Capenda, 32, também foi atingido?

Logo imediatamente parei de comer. Nervoso, comecei a respirar fundo, pensando sobre o que ia fazer. Encontrava-me desse jeito, pois acabava de voltar de um seminário na

\footnotetext{
${ }^{7}$ DISCUSSÃO DE BAR TERMINA com estudante angolana morta. Estadão, São Paulo, 23 maio 2012. Disponível em: http://noticias.uol.com.br/ultimas-noticias/agencia-estado/20I2/05/23/discussao-de-bartermina-com-universitaria-morta.htm. Acessado em 23 maio 2012.
} 
Universidade Estadual de São Paulo (Unesp) ${ }^{8}$, Campus de Araraquara, onde discutíamos a situação de violência à que estavam submetidos os imigrantes africanos, especialmente os estudantes e, no entendimento dos participantes do evento, o racismo à brasileira estaria na base dessa violência.

Portanto, a recepção dessa notícia lembrou-me, de repente, dos debates públicos sobre os assassinatos que assolam a juventude negra no Brasil ${ }^{9}$. Eu tinha que agir como intelectual e ativista. É dessa forma que acionei o meu capital cultural e político (BOURDIEU, 200I, 2002) para tornar público o acontecimento. Atrasei a minha ida para a universidade e escrevi, na qualidade de diretor do IDDAB, o texto: "Morte da estudante angolana interpela a comunidade africana para a ação”.

Acabamos de receber a notícia triste de que uma discussão de bar entre estudantes africanos angolanos com alguns clientes brasileiros acabou em morte de uma universitária angolana e ferimento dos outros em São Paulo.

Esse fato é mais um que faz o quadro triste de não proteção dos cidadãos africanos, sobretudo os estudantes, no território brasileiro. A transferência do racismo contra os negros-brasileiros para os corpos dos negrosafricanos é uma das explicações dessa violência que tende quase ao genocídio dos africanos no país: o fato de ser negro se torna o motivo de eliminação dos portadores da negritude.

Se não é a polícia que comete essas ações bárbaras, são os cidadãos brasileiros comuns que o fazem. Pois, na sua mente, acreditam que o corpo negro não vale nada e o corpo negro-africano pior ainda. Essa prática racista e desumana para ser compreendida deve-se acionar a arqueologia da escravidão racial das plantações e o racismo do século XIX, que deixaram suas marcas nas estruturas sociais e burocráticas dos séculos $\mathrm{XX}$ e XXI no Brasil. Essas práticas andam contra os direitos humanos e da Constituição Brasileira ${ }^{10}$.

\footnotetext{
${ }^{8}$ UNESP debate racismo contra africanos em Araraquara, SP. GI, I6/05/2012. Disponível em: http:/gi.globo.com/sp/araraquara-regiao/noticia/20I2/o5/unesp-debate-racismo-contra-alunos-africanos-emararaquara-sp.html. Acessado em 25 set. 2015.

${ }^{9} \mathrm{E}$ estava ciente das publicações a respeito: Cf. PNUD (2005); PAIXÃO; CARVANO, 2008; PAIXÃO; ROSETTO; CARVANO, 20Io. O estudo mais recente sobre a violência sobre a juventude negra é de WAISELFIZ (20I4).

io Disponível em: http://iddab.wordpress.com/2012/05/23/a-morte-da-estudante-angolana-interpela-acomunidade-africana-para-uma-acao/. Acessado em 23 maio 2012.
} 
Além de postar a notícia no blogue do IDDAB, compartilhei o meu texto com os amigos no meu e-mail, avisando, sobretudo aqueles que trabalham com a temática da migração.

Logo em seguida recebi respostas de alguns amigos indignados com o acontecido. $\mathrm{O}$ grande impulso para uma ação coletiva me veio da resposta que o Centro de Direitos Humanos e de Cidadania do Imigrante (CDHIC) deu à nota escrita por mim, no dia 23 de maio. A nota de apoio dessa instituição tinha por título: "Repúdio pelo assassinato da estudante angolana Zulmira e apoio à nota do IDDAB”.

O Centro de Direitos Humanos e Cidadania do Imigrante (CDHIC), uma organização da sociedade civil que tem como objetivo promover e articular ações que visem à construção de políticas públicas migratórias em respeito aos Direitos Humanos dos imigrantes e suas famílias no Brasil torna público seu repúdio diante do fato noticiado dia 22 de maio, em que a jovem angolana Zulmira Cardoso foi morta e outros quatro imigrantes angolanos foram gravemente feridos em um bar na região do Brás, em São Paulo.

Os agressores, minutos antes haviam ofendido os angolanos com frases de cunho racista. A jovem Zulmira comemorava ali com os amigos seu aniversário de 27 anos. O fato causa grande indignação e revolta! Inaceitável! Não há outra forma de se referir a este episódio: inaceitável. É por isso que declaramos aqui nosso apoio e endosso à nota publicada pelo Instituto do Desenvolvimento da Diáspora Africana no Brasil (IDDAB), [...]

Registramos nossa solidariedade com as comunidades de Angolanos no Brasil e manifestamo-nos favoráveis às mobilizações, protestos e pedidos de Justiça para esse caso, como o protesto ocorrido no Rio de Janeiro e de outros grupos organizados que denunciam o Genocídio da Juventude Negra.

Que as autoridades ajam séria e rapidamente na apuração dos crimes e apoio às vítimas e familiares. Resta uma pergunta: qual seria a reação das autoridades brasileiras se uma jovem brasileira residente no exterior e outros quatro amigos fossem baleados por motivação xenofóbica? Estariam em silêncio? (Grifo do autor) ${ }^{\mathrm{II}}$.

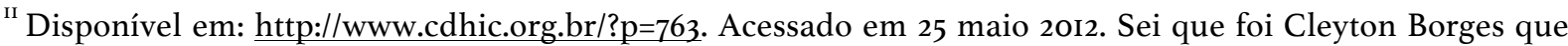
escreveu essa carta não somente pelo seu conteúdo e estilo, mas pela confissão que ele me fez, pois, tínhamos uma sinergia e parceria incríveis na condução dessa mobilização política.
} 
Estrategicamente, quem a escreveu, o advogado e ativista do CEDHIC e da UNEAFRO, Cleyton Borges ${ }^{\mathrm{I} 2}$ escolheu o dia 25 de maio (que é o Dia da África) de 2012 para denunciar a morte da Zulmira Cardoso, e ainda essa nota de apoio foi escrita na grande metrópole do Brasil, São Paulo, onde se concentra o grande número dos imigrantes e das mídias do país.

\section{Movimento “Mobilização Zulmira Somos Nós!"}

A minha consciência política relativa à luta contra o racismo e a opressão começou desde a RDCongo, meu país de origem. Apesar disso, o grande aprendizado se deu no Brasil, na minha circulação dentro do movimento negro e, sobretudo, dentro do IDDAB, a instituição da qual sou um dos fundadores e assumi a sua presidência em 2008.

A nossa movimentação, durante a anistia, para assegurar o acesso aos imigrantes, inclusive aos africanos, o direito de residência (LEITE, 20II), tem me ensinado como trabalhar com a imigração no meio dos movimentos sociais e a fazer política. Depois que recebi o retorno do CDHIC, disse a mim mesmo que era preciso acionar a rede das associações que trabalham com a imigração. Logo o IDDAB e o CDHIC, representados, respectivamente, pelo autor deste texto e por Cleyton Borges, começaram a trabalhar juntos.

Outra parceira que veio a se envolver foi a Lúcia Udemezue, socióloga, ativista nigeriano-brasileira. $\mathrm{Na}$ época, ela trabalhava como assessora do vereador do Partido dos Trabalhadores, Carlos Neder. Foi este vereador que arrumou um espaço no seu gabinete na Câmara Municipal de São Paulo para a realização da primeira reunião que aconteceu no dia 30 de maio de 2012 (NADER, 200I2).

Depois de um concerto entre essas três entidades, duas da sociedade civil e uma da instância política partidária, concordamos que era preciso chamar algumas entidades que lidam com a imigração e outras que trabalham com a causa africana ou afro-brasileira. $\mathrm{O}$ sucesso dessa primeira reunião deu força a outras estratégias e ações. Os estudantes africanos, especialmente angolanos, as entidades do movimento negro, as associações de defesa de direitos humanos e de imigrantes que tomaram parte desta reunião se juntaram num movimento que foi batizado pelo jornalista e ativista negro Hugo Ferreira Zambukaki

\footnotetext{
${ }^{12}$ Cleyton Borges, na época, trabalhava como advogado no Centro de Direitos Humanos e de Cidadania da Imigração (CDHIC) e continuou a atuar igualmente na União de Núcleos de Educação Popular (UNEAFRO BRASIL) para os Negros e Classe Trabalhadora, associação do movimento negro, de que ele é um dos fundadores.
} 
de "Mobilização Zulmira Somos Nós"[3]. De fato, foi um movimento político que agregou os imigrantes africanos e não africanos em torno da morte desta estudante.

Depois da primeira, seguiram-se outras reuniões e manifestações. Cada entidade dos imigrantes ou apoiadoras da causa da Zulmira se articulava de sua maneira para exigir justiça. As reuniões para a elaboração das estratégias coletivas foram feitas na Câmara Municipal de São Paulo. O que se decidiu foi a construção de um plano de ação assente na pressão das autoridades, a escrita de uma Representação à Presidência da República, de outros ofícios e textos, cobrando soluções e tornando público o caso via mídias sociais, rádios e televisões alternativas.

Dentro do conjunto das ações para a comemoração de um mês da morte da Zulmira, as entidades de movimentos sociais envolvidas realizaram, no dia 2I de junho de 20I2, às I6h, no Pátio do Colégio, em frente à Secretaria de Justiça do Estado de São Paulo, um ato de protesto cobrando das autoridades estaduais a justiça e a celeridade na apreensão e julgamento dos acusados (PROTESTO CONTRA O ASSASSINATO..., 20I2).

No dia seguinte, 22, às I8h, na sede de EDUCAFRO, na Rua Riachuelo, 268 (Sala São Francisco) foi feito um ato inter-religioso. Foi acordado, igualmente, a realização de uma homenagem pública, no mesmo dia, que marcava um mês da morte da Zulmira e isso aconteceu algumas horas depois, no bairro Brás, antes do ato ecumênico. Como gesto de solidariedade, foram depositadas flores e velas no local. A EDUCAFRO, junto com outras associações, transmitiu à sociedade suas mensagens de repúdio contra o racismo e assassinatos de negros brasileiros e africanos (PROTESTO CONTRA O ASSASSINATO..., 20I2).

No dia 28 de julho, foi realizada uma Audiência Pública sobre o caso da morte da Zulmira e a insegurança que ameaça a vida dos imigrantes africanos em São Paulo. A Comissão de Defesa dos Direitos Humanos, Cidadania, Segurança Pública e Relações Internacionais da Câmara Municipal de São Paulo e o gabinete do vereador Nader zelaram pela organização da Audiência Pública, que, entre outras autoridades, convocou Ribamar Dantas, membro-conselheiro do Conselho Nacional da Imigração (CNIg) ligado ao Ministério do Trabalho e Emprego (MTE).

\footnotetext{
${ }^{13}$ É o nome com que esse ativista do movimento negro e jornalista assina suas matérias. Durante os acontecimentos mostrou a sua afiliação com o Educação e Cidadania de Negros (as) e Pessoas de Camadas Populares (EDUCAFRO São Paulo), associação do movimento negro coordenada pelo Frei Davi Raimundo; e como jornalista, fez a cobertura do evento Zulmira através de um blogue e uma página do Facebook que levam o nome de "Zulmira Somos Nós!" Disponível em: http://zulmirasomosnos.blogspot.com.br/. Acessado em 30 maio 2015. O blogue trabalha numa lógica de agregar as lutas dos imigrantes africanos às lutas de negros brasileiros e tem tido sucesso na opinião pública.
} 
$\mathrm{Na}$ ocasião, coube ao CDHIC, através do seu representante Cleyton Borges, o encaminhamento da Representação ${ }^{14}$ para a Presidência da República, com cópia para o Ministério da Justiça, o Ministério das Relações Exteriores, a Secretaria Especial de Direitos Humanos, a Secretaria de Políticas para as Mulheres e a Secretaria Especial de Promoção de Políticas de Igualdade Racial (SEPPIR), exigindo justiça no caso do assassinato da Zulmira de Souza Borges Cardoso e tomada de providências contra a violência, o racismo, a discriminação, a xenofobia dos quais os africanos vinham sendo vítimas no país (ANGOLA ZULMIRA CARDOSO..., 20I2; PROTESTO CONTRA O ASSASSINATO..., 20I2).

Essa Representação foi assinada, no dia 28 de junho de 20I2, por todas as entidades envolvidas na luta por justiça pela morte de Zulmira. Em termos de conteúdo, assinalo, abaixo, alguns de seus elementos de destaque.

O “Assunto" para sua identificação foi esse: "Representação - violência e racismo contra imigrantes africanos". Em seguida, o redator escreveu: "Reunidas em razão da indignação e tristeza pela morte da jovem estudante angolana Zulmira de Souza Borges Cardoso, ocorrida em São Paulo, no bairro Brás em 22 de maio de 2012, as associações, movimentos sociais, entidades negras, grupos culturais e ativistas que abaixo subscrevem, vêm respeitosamente até a Vossa Excelência [Presidenta Dilma Russeff] apresentar REPRESENTAÇÃO com PEDIDO DE PROVIDÊNCIA, fazendo com base nos argumentos fáticos, jurídicos e políticos que a expõe" (p. I; grifos do autor).

O primeiro ponto da Representação é “O FATO” (p. I-2). Nesse ponto, a Representação narra o acontecimento, o assassinato e as manifestações que se seguiram a partir das informações oriundas da mídia. Na realidade, uma boa parte das notícias deste item nos chegou pelos estudantes angolanos; e outras, que têm a ver com as manifestações, foram protagonizadas pelas nossas organizações da sociedade civil.

Ainda no mesmo ponto, a Representação denuncia a lentidão no tratamento do caso da parte da justiça estadual e exigia que o governo federal assumisse a investigação.

O segundo ponto de destaque é a denúncia sobre a "VIOLÊNCIA CONTRA NEGROS BRASILEIROS E IMIGRANTES” (p. 2). De fato, os acontecimentos ocorridos em torno da morte da Zulmira foram um momento de negociação de agendas de movimentos sociais dos negros brasileiros e imigrantes africanos e não africanos. Das reflexões feitas durante as audiências, reuniões e manifestações chegou-se a um consenso de que todos esses sujeitos eram vítimas do racismo à brasileira, que opera pela violência simbólica e

14 “ZULMIRA SOMOS NÓS!”. Representação à Excelentíssima Presidenta da República do Brasil. São Paulo, 28 de junho de 2012. 
física e leva a mortes. Nesse ponto, o redator faz menção de algumas publicações científicas sobre a violência contra a população negra brasileira (por exemplo, A Cor da morte, publicada por Luís Eduardo Batista e colaboradores, na Revista de Saúde Pública, em 2004) e cita igualmente a nota do IDDAB.

O terceiro ponto da Representação é sobre o "GENOCÍDIO DA JUVENTUDE NEGRA” (p. 3) brasileira. Esse ponto entrou na agenda por causa das organizações do movimento negro que participaram intensamente da mobilização pela morte da Zulmira. Além disso, como já dito, sem a compreensão desta realidade torna-se difícil o entendimento do racismo e a violência contra os imigrantes negros, haitianos e africanos no país ${ }^{15}$.

Dentro desta lógica é que o ponto quatro da Representação é o "RESGATE HISTÓRICO E OUTROS CASOS RECENTES” (p. 4). O texto denunciou os casos que ocorreram até aquele período em todo território nacional e que foram notificados nas mídias. O recurso argumentativo usado continua sendo o racismo à brasileira e o mito da democracia racial que faz com que a sociedade não perceba ou não queira perceber o que acontece com suas vítimas.

O quinto ponto aponta para o Estado brasileiro a "NECESSIDADE DE REVISÃO DA LEGISLAÇÃO MIGRATÓRIA" (p. 4-5). Denuncia o caráter policial da legislação atual, por ser oriunda do contexto da ditadura militar no país, e sinaliza a necessidade de se elaborar e aprovar uma nova legislação pautada no paradigma dos direitos humanos.

O sexto ponto mostra a necessidade de "INCLUSÃO DE AGRAVANTE POR MOTIVO RACIAL NOS CRIMES COMUNS", na nova legislação penal, que estava sendo debatida na época.

O sétimo ponto cuidou de trazer os "PEDIDOS" (p. 6). Alguns dos pedidos foram atendidos, por exemplo, o governo federal acionou a SEPPIR, o Ministério da Justiça e o CNIg/MTE para que acompanhassem de perto o caso e abrissem um canal de diálogo com as associações. O que foi feito. Sobre outro pedido, o da substituição da Polícia Federal por

\footnotetext{
${ }^{15}$ HEBMÜLER, Paulo. Imigrantes negros que chegam ao Brasil deparam-se com "racismo à brasileira”, diz sociólogo. Operandi Mundi, I7 out. 20I0. http://operamundi.uol.com.br/conteudo/samuel/41983/imigrantes+negros+que+chegam+ao+brasil+deparamse+com+racismo+a+brasileira+diz+sociologo.shtml.

Acessado em I7 out. 20I5; SPERB, Paula. Imigrante senegalês é incendiado enquanto dormia em calçada no RS. Folha, São Paulo, I2 set. 20I5. Disponível em: http://wwwi.folha.uol.com.br/cotidiano/2015/09/1681043imigrante-senegales-e-incendiado-enquanto-dormia-em-calcada-no-rs.shtml. Acessado em I2 set. 20I5; SARTORI, Tríssia Ordavás. Senegaleses protestam em Caxias contra a insegurança. Pioneiro, 2 fev. 2016. Disponível em: http://pioneiro.clicrbs.com.br/rs/geral/cidades/noticia/2016/o2/senegaleses-protestam-emcaxias-contra-a-inseguranca-4985581.html. Acessado em 2 fev. 20I6; e EM FOZ, FACISTAS CULPAM DILMA pela presença de haitiano e passam a espanca-lo. Coletiva Mídia Livre/VIOMUNDO, I5 maio 20I6. Disponível em: http:/www.viomundo.com.br/denuncias/em-foz-fascistas-culpam-dilma-pela-presenca-de-haitiano-epassam-a-espanca-lo.html. Acessado em I5 maio 2016.
} 
um novo órgão da administração federal no trato da questão migratória, não tive ainda uma resposta satisfatória.

Figura 3: Primeira reunião da mobilização na Sala Tiradentes, Câmara Municipal de São Paulo, 30 de maio de 2012

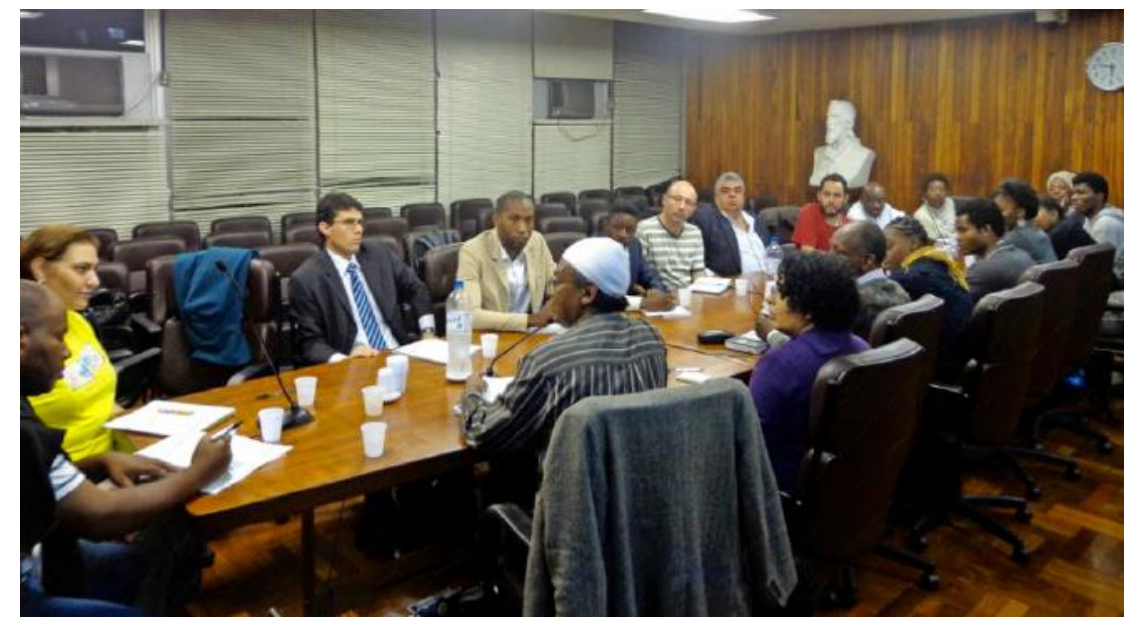

Fonte: Hugo Ferreira (2012).

Alguns agentes sociais se destacaram no desenvolvimento da publicização da luta pela reivindicação da justiça em torno da morte da Zulmira: o CDHIC e o IDDAB, representados pelo Cleyton Borges e Bas' Ilele Malomalo; o movimento "Zulmira Somos Nós!", liderado pelo jornalista Hugo Ferreira, que atuava junto com o Frei Davi da EDUCAFRO. Os representantes dessas entidades trabalhavam em colaboração com os estudantes angolanos que se articularam numa plataforma denominada Associação da União dos Estudantes Angolanos.

O CDHIC e o IDDAB abriram uma linha de combate que alcançou as autoridades de Brasília e deve ter chegado a esse nível por haver coordenado as atividades que aconteciam na Câmara Municipal e se responsabilizado pelo envio da Representação à Presidência da República. Além disso, souberam usar do poder simbólico (BOURDIEU, 200I) das mídias alternativas para atingir os objetivos da luta, que era a denúncia e a cobrança da justiça da parte das autoridades. 
Figura 4: Reunião entre as associações dos imigrantes e os representantes de CNIg/MTE, Ouvidoria Nacional da SEPPIR e Secretaria do Ministério da Justiça. São Paulo, Superintendência do Trabalho/TEM, I3 de julho de 2012

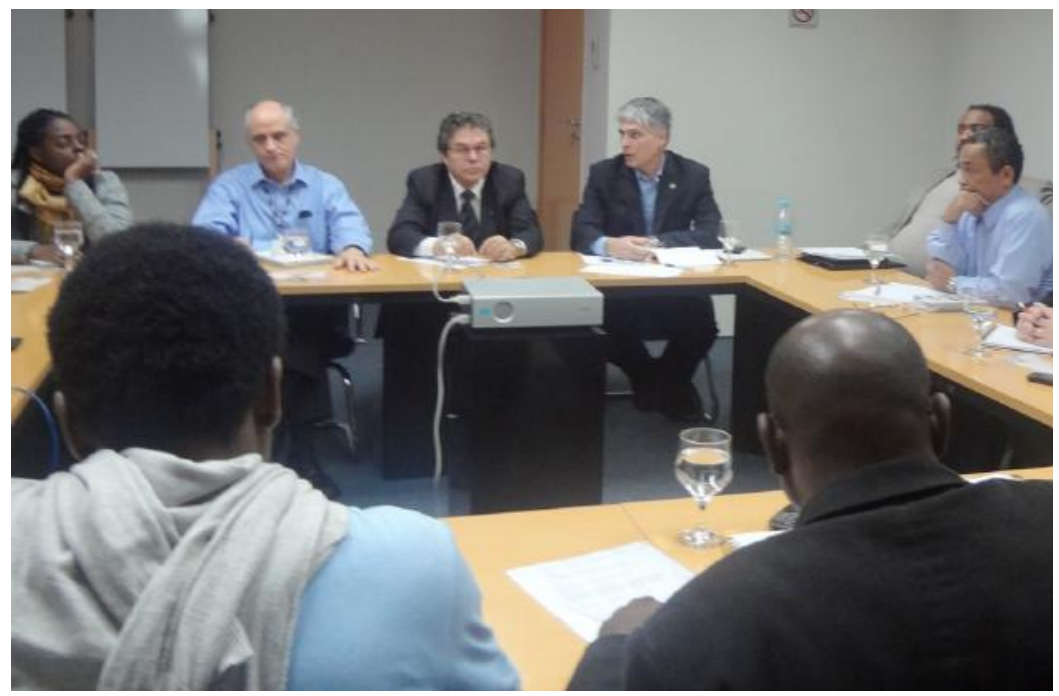

Foto: Wilbert Rivas/CDHIC (2012).

A alta pressão das organizações sociais reunidas em torno da morte da Zulmira junto às autoridades e a repercussão que teve na mídia nacional e internacional, fez com que o governo federal constituísse um grupo de trabalho (GT) sobre o assunto. Seus integrantes foram: os representantes de CNIg/MTE da Ouvidoria Nacional da SEPPIR e da Secretaria do Ministério da Justiça. No dia 13 de julho de 20I2, convocaram uma reunião com as entidades que tratavam do caso da Zulmira, que ocorreu na Superintendência do Trabalho/TEM-SP. As entidades sociais que participaram desta reunião são: IDDAB, UNEA-SP, CDHIC, UNEAFRO, Associação União de Estudantes Angolanos, Missão Paz, Casa do Imigrante, Conselho da Comunidade Peruana, Presença da América Latina e Rede Espaço Sem Fronteiras (PROTESTO CONTRA O ASSASSINATO..., 20I2; RIVAS, 2012).

Durante essa reunião, um dos representantes do governo federal informou que um dos suspeitos na morte da Zulmira foi preso e que assumia o compromisso de encontrar os outros envolvidos, que tinham fugido. As entidades presentes colocaram na pauta, também, os problemas de violência, discriminação e racismo que afetam a vida dos imigrantes sul-americanos. Dessa reunião, o que se percebeu é que o governo federal ficou sensibilizado pelos problemas que estavam acontecendo e, para a sua resolução, formou um GT.

No dia 12 de setembro de 20I2, o autor deste texto e o Cleyton Borges do CDHIC foram convocados pelo CNIg/MTE, em Brasília, para discutir os problemas dos estudantes africanos e apresentar propostas. A reunião foi muito produtiva. Foi um momento de 
reafirmação dos compromissos já estabelecidos entre os representantes do governo federal e as entidades dos imigrantes ou apoiadores das causas dos imigrantes que o caso da Zulmira tinha trazido à tona.

Figura 5: Conselho Nacional da Migração (da esquerda para a direita) - Carlos Alberto (Ouvidoria da SEPPIR), Bas'Ilele Malomalo (IDDAB), Cleyton Borges (CDHIC) e Paulo Sergio de Almeida (CNIg/MTE), Brasília, I2 de setembro de 2012

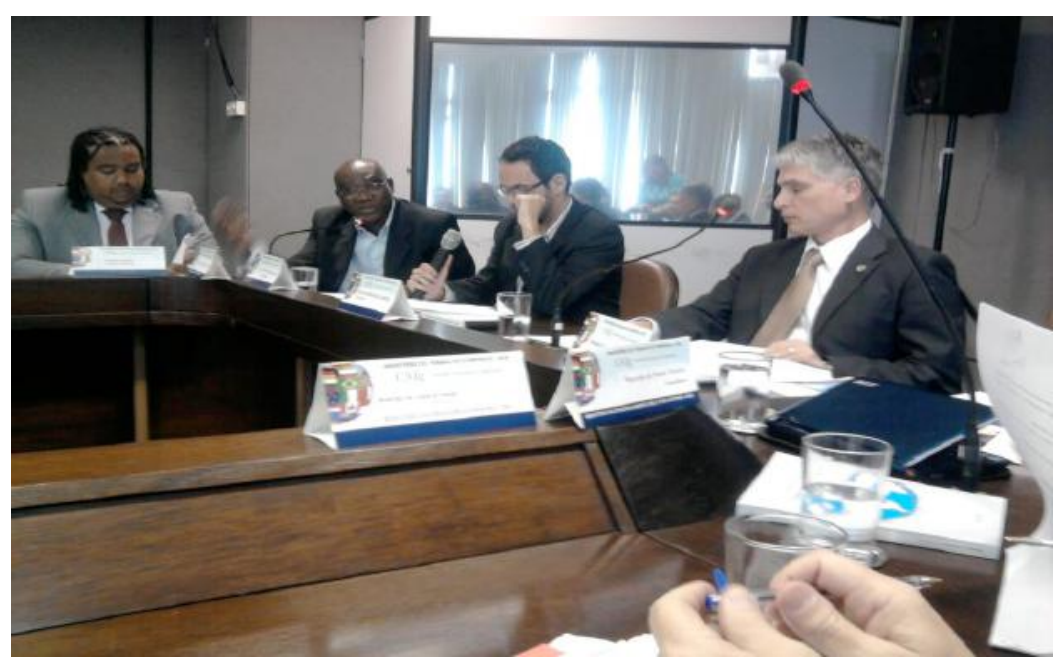

Foto: Cleyton Borges (2012).

A EDUCAFRO foi igualmente um agente importante na luta pela justiça à morte da Zulmira, pela mediação do Frei Davi e do jornalista Hugo Ferreira. A imagem da "Figura 6" faz parte de uma mensagem que aquele jornalista postou no dia 26 de fevereiro de 2013, faltando três meses para a o aniversário da morte da Zulmira. A forma como ele constrói o texto revela, primeiro, a decepção da comunidade negra, entenda-se afro-brasileira e africana, junto com o caso de outros imigrantes perante a demora da justiça na captura dos assassinos. Por isso o questionamento: "Quem matou a Zulmira Cardoso?" dele em lembrar a sociedade o seu desespero e decepção por causa do tempo que se passara sem solução. "Quase um ano se passou da 'tentativa de massacre do Brás”, isto é, fixa os leitores no lugar em que a Zulmira, "irmã negra angolana" padeceu pelos tiros de seus assassinos.

${ }^{16}$ QUEM MATOU a Zulmira Cardoso. “Zulmira Somos Nós!", 23 fev. 20I3. Disponível em: http://zulmirasomosnos.blogspot.com.br/2013/o2/quem-matou-zulmira-cardoso.html. Acessado em 23 fev. 2013. 
De qualquer forma, a mensagem traz também notas de esperança, relembrando a repercussão que o caso teve na mídia internacional por causa das lutas que os movimentos sociais dos negros e dos imigrantes travaram (QUEM MATOU..., 20I3).

Figura 6: Homenagem a Zulmira depois de quase um ano da sua morte, São Paulo

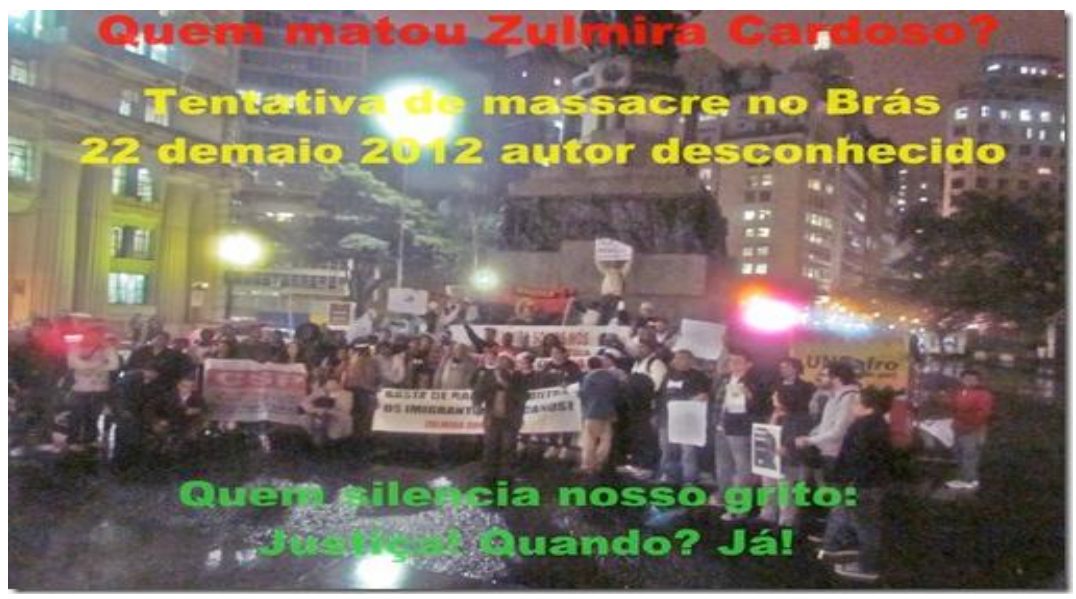

Fonte: ZULMIRA SOMOS NÓS! (2013).

Todavia, é preciso afirmar que nem tudo foi sucesso no caso da Zulmira. O governo angolano preferiu aguardar uma posição diplomática perante a situação. Houve um momento de intimidação da parte de alguns representantes da sua embaixada para com os estudantes envolvidos no movimento “Mobilização Zulmira Somos Nós!”, pois achavam que as manifestações que faziam expunham os governos angolano e brasileiro. Dentro deste contexto é que a família da Zulmira não queria se comunicar com os representantes, publicamente, do movimento. Além disso, as entidades envolvidas na investigação da morte da Zulmira ficaram decepcionadas com a lentidão do tratamento que ela vinha recebendo da parte das autoridades competentes do governo federal, e estadual de São Paulo.

De qualquer modo, mesmo não atuando de forma coordenada, o trabalho de denúncia e pressão (ANGOLANOS EXIGEM..., 2012) ${ }^{17}$ na esfera pública feito pelas

\footnotetext{
${ }^{17}$ Ver igualmente: ESTUDANTES ANGOLANOS exigem desculpas do governo brasileiro e pedem investigações. $\quad T V T$. Vídeo. 29 jun. $2012 . \quad$ Disponível http://www.tvt.org.br/watch.php?id=9987\&category=200. Acessado em 29 jun. 20I2; ESTUDO MAPEARÁ imigrantes africanos, e estudantes terão maior assistência. Rádio Agência NP. Áudio. I7 set. 2012. http://www.radioagencianp.com.br/IIo85-estudo-mapeara-imigrantes-africanos-e-estudantes-terao-maiorassistencia. Acessado em I7 set. 20I2; JORNALISMO COLABORATIVO: imigrantes denunciam assassinatos e agressões em SP. TVT. Vídeo. 25 jun. 2012. Disponível em: http://www.tvt.org.br/watch.php?id=9929\&category=203. Acessado em 25 jun. 20I3;

KAHANGA. Zulmira Descanse em Paz. Música. Disponível: http://letras.mus.br/kanhanga/zulmira-descanseem-paz/. Acessado em 26 fev. 20I3; MOVIMENTOS SOCIAIS apresentam propostas de combate ao racismo ao Conselho Nacional de Imigração. TVT. Vídeo. I4 set. 20I2. Disponível em:
} 
organizações sociais e o trabalho de investigação feito pelas autoridades, o governo de Angola, que tinha contratado um advogado desde o início, os representantes do governo federal brasileiro, que acompanharam o caso, tiveram um resultado positivo depois de três anos. Pois, no dia 24 de março de 2015, um dos envolvido na morte da Zulmira foi julgado e condenado a 37 anos de prisão.

O jornal ANGOP - Angola Agência Press ${ }^{\text {I8 }}$ - inicia a sua matéria com estas considerações:

Luanda - Um dos participantes no assassinato da cidadã angolana Zulmira de Souza Borges Cardoso (em maio de 20I2), foi condenado pelo Tribunal Criminal brasileiro na Barra Funda (Brasil) a 37 anos de cadeia em regime fechado.

A mesma fonte consultada afirma que o outro envolvido, o suposto autor dos disparos, só não foi condenado porque seu processo estava ainda tramitando na justiça para um julgamento (CONDENADO BRASILEIRO..., 20I5).

Lembro-me, como se fosse ontem, do nosso alívio no sentido de que vale a pena lutar pela justiça, quando essa notícia começou a circular pelos veículos da mídia. Trocamos impressões entre nós e o sentimento que prevalecia e prevalece até hoje é que a nossa luta continua para que os direitos dos imigrantes sejam respeitados.

http://www.tvt.org.br/watch.php?id=I0857\&category=205. Acessado em I4 set. 20I2; MALOMALO, Bas' Ilele. Entrevista. CDHIC, São Paulo, II nov. 20I2. Disponível em: http://www.cdhic.org.br/wpcontent/uploads/20I2/II/Conexi\%C3\%B3n-MigranteI4.pdf. Acessado em II nov. 20I2; MORTE DE ANGOLANA reacende polêmica sobre o racismo no Brasil. TVT. Vídeo, I4 jun. 20I2. Disponível em: http://www.tvt.org.br/watch.php?id=9798\&category=203. Acessado I4 jun. 20I2; PROFESSOR CONGOLESS comenta violência e racismo contra imigrantes africanos no Brasil. Rádio Agência NP. Áudio. 24 jul. 2012. http://www.radioagencianp.com.br/node/I0933. Acessado em 24 de jul. 20I2; PROTESTO CONTRA O ASSASSINATO da angola Zulmira será nos dias 2I e 22 em SP. CSP com Lutas, São Paulo, 20 jun. 2012. Disponível em: http://cspconlutas.org.br/2012/o6/protesto-contra-o-assassinato-de-zulmira-estudante-angolaassassinada-por-racistas-sera-nesta-quinta-2I-em-sp/. Acessado em 20 jun. 2012; SUSPEITO DE MATAR estudante angolana é preso em São Paulo. Rádio Agência NP. Áudio. I2 jul. 20I2. Disponível em: http://www.radioagencianp.com.br/node/I0929. Acessado em I2 jul. 20I2; RIVAS, Wilbert. Por políticas para imigrantes africanos, entidades mobilizam três Ministérios. Jornal Conexión Migrante - CDHIC, São Paulo, 20 jul. 20I2. http://iddab.wordpress.com/20I2/o7/20/por-politicas-para-imigrantes-africanos-entidadesmobilizam-tres-ministerios/. Acessado em em 20 jul. 20I2; REPÚDIO PELO ASSASSINATO da estudante angolana Zulmira e apoio à nota do IDDB. CDHIC, 25 maio 20I2. Disponível em: http://www.cdhic.org.br/?p=763. Acessado em 25 maio 2012.

${ }^{18}$ CONDENADO BRASILEIRO envolvido no assassinato da angolana Zulmira Cardoso. Agência Angola Press, Luanda, 4 mar. 2015. Disponível em: http://www.portalangop.co.ao/angola/pt_pt/noticias/sociedade/2015/2/Io/Angola-Condenado-brasileiroenvolvido-assassinato-angolana-Zulmira-Cardoso,7bc57039-e789-426c-a7a4-d5dd4278c9d8.html. Acessado em 4 março 2015. 


\section{Considerações finais}

Para finalizar a minha narrativa a respeito da história de mobilização coletiva sobre os imigrantes africanos que compõem as diásporas de São Paulo, retorno mais uma vez a um trecho do sociólogo brasileiro Octávio Ianni sobre a experiência de migração.

O migrante pode ser um e muitos, famílias e grupos, coletividades e povos. São viandantes de uma vasta e errática diáspora que se espalha pelas nações e continentes, com suas vozes e línguas, cores e coloridos, atividades e padecimentos, frustrações e alegrias. Podem realizar-se na primeira ou na última geração; ou malograr-se por todas. Estão metidos em situações e acontecimentos, guerras e convulsões sociais, lutas políticas e revoluções, carências e esperanças. Podem ser vistos como uma multidão em movimento, ao acaso de situações e acontecimentos, como que atingidos pelos ventos. (IANNI, 2004a, p. 93).

O texto de Ianni nos leva a perceber de que forma o caso da morte da Zulmira se colocou como uma mobilização política dos africanos pelos seus direitos coletivos. Tudo isso aconteceu porque a articulação, que iniciou com a nota do IDDAB, encontrou a solidariedade de outras organizações sociais que lutam contra o racismo e/ou trabalham em prol dos direitos dos imigrantes.

Zulmira foi escolhida por elas como o símbolo da resistência e da luta pelo estabelecimento da justiça perante o racismo, a violência e a insegurança que afetam os negros brasileiros, os imigrantes africanos e outros, como os bolivianos e paraguaios.

As estratégias que essas associações montaram funcionaram. Cada uma cuidou da sua parte e soube trabalhar coletivamente. O movimento "Mobilização Zulmira Somos Nós!" deu sustentação à longa luta, de 2012 até 20I5, quando um dos assassinos foi julgado e condenado.

Toda essa história revela quanto a situação dos imigrantes africanos na Diáspora Brasileira é marcada pelas aflições causadas pela violência e o racismo estrutural. A superação dessa situação passa pela ativação da solidariedade e pela realização da luta pelos direitos que exige sacrifícios, determinações e resistências. Sem isso, não há direito de esperança, o direito de viver em paz e de segurança e o direito de migrar e ser diferente. 


\section{Referenciais bibliográficas}

ANTONACCI, Maria Antonieta. Memórias ancoradas em corpos negros. São Paulo: EDUC, 2015.

BÂ, Amadou Hampâté. Amkoullel, o menino Fula. 2. ed. São Paulo: Pallas Athenas: Casa das Áfricas, 2003.

BENTO, Maria Aparecida Silva. Branqueamento e branquitude no Brasil. In: CARONE, Iray; BENTO, Maria Aparecida Silva. Psicologia social do racismo - Estudos sobre branquitude e branqueamento no Brasil. Petrópolis: Vozes, 2002, p. 25-58.

BOURDIEU, Pierre. O poder simbólico, 5. ed. Rio de Janeiro: Bertrand Brasil, 2002.

. Sciences de la science et réflexivité: cours du collège de France 2000-200I. Paris: Raison d'Agir, 200I.

. Ce que parler veut dire: l'économie des échanges linguistiques. Paris: Fayard, 1982.

CASANOVA, Pablo González. As novas ciências e as humanidades: da academia à política. São Paulo: Boitempo, 2006.

D'ADESKY, Jacques. Pluralismo étnico e multiculturalismo: racismo e anti-racismo no Brasil. Rio de Janeiro: Pallas, 200I.

DESIDÉRIO, Edilma de Jesus. Migração internacional com fins de estudo: o caso dos africanos do Programa Estudante-Convênio de Graduação em três universidades públicas no Rio de Janeiro. Dissertação de mestrado. Escola Nacional de Ciências Estatísticas. Programa de Pós-Graduação em Estudos Populacionais e Pesquisas Sociais. Rio de Janeiro, 2006.

FAIRCLOUGH, Norman. Discurso e mudança social. Brasília: UNB, $200 \mathrm{.}$.

GIL, Antônio Carlos. Como elaborar projetos de pesquisa. São Paulo: Editora Atlas, 1996.

GILROY, Paul. O Atlântico Negro: modernidade e dupla consciência. São Paulo: Editora 34, Rio de Janeiro: Universidade Cândido Mendes, Centro de Estudos Afro-Asiáticos, $200 I$.

GOMES, Romeu. “Análise e interpretação de dados de pesquisa qualitativa”. In: MINAYO, Maria Cecília de Souza (Org.). Pesquisa social: Teoria, método e criatividade. 3I. ed. Petrópolis: Vozes, 20I2, p. 79-IO7.

GUIMARÃES, A. Sergio Alfredo. Racismo e anti-racismo no Brasil. São Paulo: Editora 34, 1999.

GUSMÃO, Neusa M. M. Na terra do outro: presença e invisibilidade de estudantes africanos no Brasil, hoje. Revista de História (UFES), 20II, v. n. 26, p. I9I-204. Disponível em: http://dialnet.unirioja.es/servlet/articulo?codigo=3724752. Acesso em 25 set. 201 I.

HALL, Stuart. A Identidade Cultural na Pós-Modernidade. II. ed. Rio de Janeiro: DP\&A Editora, 2006. 
HEYWOOD, Linda M. (Org.) Diáspora negra no Brasil. São Paulo: Contexto, 2008.

HOUNTOUNDJI, Paulin. Conhecimento de África, conhecimentos de africanos: duas perspectivas sobre os Estudos Africanos. Revista Crítica de Ciências Sociais, n. 80, março 2008, p. I49-160.

IANNI, Octávio. Capitalismo, violência e terrorismo. Rio de Janeiro: Civilização Brasileira, 2004a.

. O preconceito racial no Brasil. Estudos avançados, São Paulo: v. I, n. I, p. 6-20, jan./abr. $2004 \mathrm{~b}$.

JACCOUD, Luciana de Barros; BEGHIN, Nathalie. Desigualdades raciais no Brasil: um balanço da intervenção governamental. Brasília: IPEA: 2002.

O combate ao racismo e à desigualdade: $\mathrm{O}$ desafio das políticas públicas de promoção da igualdade racial. In: THEODORO, Mário (Org.) et al. As políticas públicas e a desigualdade racial no Brasil: I2O anos após a abolição. 2. ed. Brasília: IPEA, 2009, p. I35-I70. KALY, Alain Pascal. (200I) O Ser preto africano no "paraíso terrestre": Um sociólogo senegalês no Brasil. Lusotopia, 200I, p. I05-I2I. Disponível em: <http://www.lusotopie.sciencespobordeaux. fr/resuiooo6.html >. Acesso em 25 set. 201 I. KI-ZERBO, Joseph. "Introdução geral”. In: IDEM (Ed.). História Geral da África, I: Metodologia e pré-história da África, 2. ed. revisada. Brasília: UNESCO, 20Io, p. XXXI-LVII. LANGA, Ercílio Brandão. Diáspora africana no Ceará no século XXI: ressignificações identitárias e as interseccionalidades de raça, gênero, sexualidade e classe no contexto da migração estudantil internacional. In: MALOMALO, Bas'Ilele; FONSECA, José Dagoberto; BADI, Mbuyi Kabunda (Org.). Diáspora africana e migração na era da globalização: experiências de refúgio, estudo, trabalho. Curitiba: CRV, 2015, p. I6I-I85.

LE GOFF, Jacques. História e memória. Campinas, SP: Unicamp, 2012.

MEDRADO, Benedito. Textos em cena: a mídia como uma prática discursiva. In: SPINK, Jane Mary (Org.). Práticas discursivas e reprodução de sentidos no cotidiano: aproximações teóricas e metodológicas. São Paulo: Cortez, I999, p. 243-27I.

MALOMALO, Bas'Ilele. Filosofia do Ubuntu: Valores civilizatórios das ações afirmativas para o desenvolvimento. Curitiba: CRV, 2014.

MALOMALO, Bas'Ilele; FONSECA, José Dagoberto; BADI, Mbuyi Kabunda (Org.). Diáspora africana e migração na era da globalização: experiências de refúgio, estudo, trabalho. Curitiba: CRV, 2015.

MORIN, Edgar. Os sete saberes necessários à educação do futuro, 2. ed. São Paulo: Cortez; Brasília, DF: UNESCO, 201 . 
MUNANGA, Kabengele. Rediscutindo a mestiçagem no Brasil: identidade nacional versus identidade negra. Petrópolis: Vozes, 1999.

ORLANDI, Eni Pucinelli. Análise de discurso: princípios \& procedimentos, I2. ed. Campinas, SP: Pontes, 2012.

PAIXÃO, Marcelo; CARVANO, Luiz M. (Org.). Relatório anual das desigualdades raciais no Brasil 2007-2008. Rio de Janeiro: Gramond, Laeser, 2008.

PAIXÃO, Marcelo; ROSSETTO, Irene; CARVANO, Luiz M. (Org.). Relatório anual das desigualdades raciais no Brasil 20o8-20Io. Rio de Janeiro: Gramond, Laeser, 2010.

PNUD. Relatório do Desenvolvimento Humano - Brasil 2005. Racismo, pobreza e violência. Disponível em: www.pnud.org.br. Acessado em I5 dez. 2005.

SILVA, Petronilha Gonçalves; SILVÉRIO, Valter Roberto. Educação e Ações Afirmativas: entre a injustiça simbólica e a injustiça econômica. Brasília: Instituto Nacional de Estudos e Pesquisas Educacionais Anísio Teixeira, 2003.

SPINK, Jane Mary (Org.). Práticas discursivas e reprodução de sentidos no cotidiano: aproximações teóricas e metodológicas. São Paulo: Cortez, I999.

SOUZA, Lorena Francisco de. Migração para qualificação da força de trabalho e a questão racial: Estudantes africanos/as lusófonos/as negros/as em universidades goianas. Tese de doutorado. Departamento de Geografia. São Paulo: FFLCH-USP, 2014.

VARGEM, Alex André; MALOMALO, Bas’ Ilele. A imigração africana contemporânea para o Brasil: entre a violência e o desrespeito aos direitos humanos. In: MALOMALO, Bas' Ilele; FONSECA, José Dagoberto; BADI, Mbuyi Kabunda (Org.). Diáspora africana e migração na era da globalização: experiências de refúgio, estudo, trabalho. Curitiba: CRV, 20I5, p. IO7-I28. VEYNE, Paul. Comment écrit-on l'histoire?. Paris : Seuil, 1957.

WAISELFISZ, Julio Jacobo. Mapa de violência: Mortes matadas por arma de fogo. SEPPIR: Brasília, 2015.

Disponível em: http://www.mapadaviolencia.org.br/pdf20I5/mapaViolencia20I5.pdf. Acessado em I5 mar. 2016.

\section{Documentos sobre o acontecimento da morte da Zulmira}

ANGOLANOS EXIGEM desculpas de Dilma, por assassinato de estudante. Radio Agência NP. Áudio. 22 jun. 2012. Disponível em: http://www.radioagencianp.com.br/node/I0873. Acessado em 22 jun. 2012.

ANGOLANA ZULMIRA CARDOSO se torna símbolo na luta por direitos de imigrantes africanos no Brasil. CDHIC, São Paulo, I8 jun. 20I2. Disponível em: http://www.cdhic.org.br/?p=225. Acessado em I8 jun. 2012. 
CONDENADO BRASILEIRO envolvido no assassinato da angolana Zulmira Cardoso. Agência Angola Press, Luanda, 4 mar. 2015. Disponível em: http://www.portalangop.co.ao/angola/pt_pt/noticias/sociedade/20I5/2/Io/AngolaCondenado-brasileiro-envolvido-assassinato-angolana-Zulmira-Cardoso,7bc57039-e789426c-a7a4-d5dd4278c9d8.html. Acessado em 4 março 2015.

DISCUSSÃO DE BAR TERMINA com estudante angolana morta. Estadão, São Paulo, 23 maio 2012. Disponível em: http://noticias.uol.com.br/ultimas-noticias/agenciaestado/2012/05/23/discussao-de-bar-termina-com-universitaria-morta.htm. Acessado em 23 maio 2012.

ESTUDANTES ANGOLANOS exigem desculpas do governo brasileiro e pedem investigações. TVT. Vídeo. 29 jun. 2012. Disponível em: http://www.tvt.org.br/watch.php?id=9987\&category=200. Acessado em 29 jun. 2012. ESTUDO MAPEARÁ imigrantes africanos, e estudantes terão maior assistência. Rádio Agência NP. Áudio. I7 set. 20I2. http://www.radioagencianp.com.br/IIo85-estudo-mapearaimigrantes-africanos-e-estudantes-terao-maior-assistencia. Acessado em I7 set. 2012.

JORNALISMO COLABORATIVO: imigrantes denunciam assassinatos e agressões em SP. $\begin{array}{llllll}\text { TVT. } & \text { Vídeo. } & 25 & \text { jun. } & \text { Disponível }\end{array}$ http://www.tvt.org.br/watch.php?id=9929\&category=203. Acessado em 25 jun. 2013.

KAHANGA. Zulmira Descanse em Paz. Música. Disponível: http://letras.mus.br/kanhanga/zulmira-descanse-em-paz/. Acessado em 26 fev. 2013. MALOMALO, Bas'Ilele. Entrevista. CDHIC, São Paulo, II nov. 20I2. Disponível em: http://www.cdhic.org.br/wp-content/uploads/20I2/II/Conexi\%C3\%B3n-MigranteI4.pdf. Acessado em II nov. 2012.

MORTE DE ANGOLANA reacende polêmica sobre o racismo no Brasil. TVT. Vídeo, I4 jun. 2012. Disponível em: http://www.tvt.org.br/watch.php?id=9798\&category=203. Acessado em I4 jun. 2012.

MOVIMENTOS SOCIAIS apresentam propostas de combate ao racismo ao Conselho Nacional de Imigração. TVT. Vídeo. I4 set. 20I2. Disponível em: http://www.tvt.org.br/watch.php?id=I0857\&category=205. Acessado em I4 set. 2012.

NADER, Carlos. Militantes cobram política pública para imigrantes africanos. Disponível em: http://www.carlosneder.com.br/site/noticias/509/militantes-cobram-politica-publicapara-imigrantes-africanos. Acessado em 30 maio 2012.

PROFESSOR CONGOLÊS comenta violência e racismo contra imigrantes africanos no Brasil. Rádio Agência NP. Áudio. 24 jul. 20I2. http://www.radioagencianp.com.br/node/ıo933. Acessado em 24 de jul. 2012. 
PROTESTO CONTRA O ASSASSINATO da angola Zulmira será nos dias 2 I e 22 em SP. CSP com Lutas, São Paulo, 20 jun. 2012. Disponível em: http://cspconlutas.org.br/2012/o6/protesto-contra-o-assassinato-de-zulmira-estudanteangola-assassinada-por-racistas-sera-nesta-quinta-2I-em-sp/. Acessado em 20 jun. 2012. QUEM MATOU a Zulmira Cardoso. Zulmira Somos Nós! 23 fev. 20I3. Disponível em: http://zulmirasomosnos.blogspot.com.br/2013/o2/quem-matou-zulmira-cardoso.html. Acessado em 23 fev. 2013.

REPÚDIO PELO ASSASSINATO da estudante angolana Zulmira e apoio à nota do IDDB. CDHIC, 25 maio 20I2. Disponível em: http://www.cdhic.org.br/?p=763. Acessado em 25 maio 2012.

RIVAS, Wilbert. Por políticas para imigrantes africanos, entidades mobilizam três Ministérios. Jornal Conexión Migrante - CDHIC, São Paulo, 20 jul. 2012. http://iddab.wordpress.com/2012/o7/20/por-politicas-para-imigrantes-africanos-entidadesmobilizam-tres-ministerios/. Acessado em 20 jul. 2012.

SUSPEITO DE MATAR estudante angolana é preso em São Paulo. Rádio Agência NP. Áudio. I2 jul. 20I2. Disponível em: http://www.radioagencianp.com.br/node/Io929. Acessado em I2 jul. 2012.

“ZULMIRA SOMOS NÓS”. Representação à Excelentíssima Presidenta da República do Brasil. São Paulo, 28 de junho de 2012.

\section{Documentos sobre migração em geral}

DENIZ, Pedro. Imigrantes africanos tomam ruas de SP e revelam diversidade de estilos. 2I/02/2016. Disponível em:

http://wwwI.folha.uol.com.br/ilustrada/20I6/02/I74I265-imigrantes-africanos-tomam-ruasde-sp-e-revelam-diversidade-de-estilos.shtml. Acessado em 2I fev. 2016.

EM FOZ, FACISTAS CULPAM DILMA pela presença de haitiano e passam a espancá-lo. Coletiva Mídia Livre/VIOMUNDO, I5 maio 20I6. Disponível em: http://www.viomundo.com.br/denuncias/em-foz-fascistas-culpam-dilma-pela-presenca-dehaitiano-e-passam-a-espanca-lo.html. Acessado em I5 maio 2016.

IMIGRAÇÃO AFRICANA no Brasil aumenta 30 vezes entre 2000 e 20I2. Terra, Io maio 20I4. Disponível em: http://noticias.terra.com.br/brasil/imigracao-africana-no-brasilaumenta-30-vezes-entre-200o-e-

20I2,bcdedc77d62e54IoVgnCLD200oooodc6eboaRCRD.html. Acessado em Io maio 2I4. HEBMÜLER, Paulo. Imigrantes negros que chegam ao Brasil deparam-se com "racismo à brasileira”, diz sociólogo. Operandi Mundi, I7 out. 20Io. Disponível em: 
http://operamundi.uol.com.br/conteudo/samuel/41983/imigrantes+negros+que+chegam+ao +brasil+deparam-se+com+racismo+a+brasileira+diz+sociologo.shtml. Acessado em I7 out. 2015.

SARTORI, Tríssia Ordavás. Senegaleses protestam em Caxias contra a insegurança. Pioneiro, 2 fev. 2016. Disponível em: http://pioneiro.clicrbs.com.br/rs/geral/cidades/noticia/20I6/o2/senegaleses-protestam-emcaxias-contra-a-inseguranca-498558I.html. Acessado em 2 fev. 2016.

SPERB, Paula. Imigrante senegalês é incendiado enquanto dormia em calçada no RS. Folha, São Paulo, 12 set. 2015. Disponível em: http://wwwI.folha.uol.com.br/cotidiano/2015/o9/I68IO43-imigrante-senegales-e-incendiadoenquanto-dormia-em-calcada-no-rs.shtml. Acessado em I2 set. 2015. 